2016-03-08

\title{
Chile's private pension system at 35: impact and lessons
}

Hyde, MB

http://hdl.handle.net/10026.1/4593

10.1080/21699763.2016.1148623

Journal of International and Comparative Social Policy

Taylor \& Francis

All content in PEARL is protected by copyright law. Author manuscripts are made available in accordance with publisher policies. Please cite only the published version using the details provided on the item record or document. In the absence of an open licence (e.g. Creative Commons), permissions for further reuse of content should be sought from the publisher or author. 


\section{Chile's private pension system at 35: impact and lessons}

\section{Silvia Borzutzky \& Mark Hyde}

To cite this article: Silvia Borzutzky \& Mark Hyde (2016) Chile's private pension system at 35: impact and lessons, Journal of International and Comparative Social Policy, 32:1, 57-73, DOI: 10.1080/21699763.2016.1148623

To link to this article: http://dx.doi.org/10.1080/21699763.2016.1148623

曲 Published online: 08 Mar 2016.

Submit your article to this journal $\widetilde{ }$

Q View related articles $\asymp$

View Crossmark data \lceil 


\title{
RESEARCH ARTICLE
}

\section{Chile's private pension system at 35: impact and lessons}

\author{
Silvia Borzutzky ${ }^{\text {a* }}$ and Mark Hyde ${ }^{\mathrm{b}}$ \\ ${ }^{a}$ Department of Political Science and International Relations, Heinz College, Carnegie Mellon \\ University, Pittsburgh, PA, USA; ${ }^{b}$ Department of Work and Pensions, Plymouth University, Plymouth, \\ $U K$
}

(Received 17 July 2015; accepted 27 January 2016)

\begin{abstract}
This paper provides an analysis of Chile's 35 year experience with defined contribution, fully funded pensions and argues that this pension approach should not be emulated by countries seeking to reduce the state role in the provision of pensions. The paper shows that 35 years of privatized pensions have led to a massive accumulation and concentration of capital and profits in the hands of the pension fund administrators and insufficient and unequal pensions for the retirees. This legacy of the Pinochet dictatorship has experienced marginal reforms after the transition to democracy. However, those reforms have not altered the system's structure and have augmented the fiscal role as the state attempts to repair some the most damaging outcomes of the private pension scheme.
\end{abstract}

Keywords: chile; Latin America; social security; privatization of pensions; retirement income; fully funded; defined contributions pensions; social policy

\section{Introduction}

This article rests on the premise that the design of social security and the distribution of retirement income are closely inter-twined. It is widely accepted in the social policy literature that universal statutory income-transfer programs, such as social insurance schemes, and non-contributory citizen's pensions, represent the most effective means of ameliorating income deprivation in old age (Hyde \& Dixon, 2009). Private pensions are typically dismissed as a neoliberal alternative that intensifies retirement income insecurity, and retiree poverty, while enriching the financial services institutions that manage worker's savings. This critique of privatization is given credibility by our analysis of Chile's pioneering system of privately administered, defined contribution (DC), pension scheme. Although privatization was justified ideologically in terms of improving the retirement prospects of workers, Chile's 35-year-old experience shows that privatization has generated insufficient pensions and retiree income inequalities, while enabling pension fund managers to generate enormous revenue streams. While subsequent reforms have improved coverage and augmented the retirement prospects of particular groups of workers, they have failed to rectify fundamental problems and forced a reengagement of the state to offset some of the failures of the private pension system. Studying the nature and impact of Chile's privately administered, DC system is critically

*Corresponding author. Email: Sb6n@andrew.cmu.edu 
important because the Chilean reform served as a model for subsequent reforms implemented throughout Latin America and Eastern Europe. These reforms that were supported and promoted by International Financial Organizations such as the World Bank and the International Monetary Fund (IMF).

Reflecting on a substantial an ongoing program of research (Borzutzky, 2002, 2010; Borzutzky \& Hyde, forthcoming; Hyde \& Dixon, 2009), we pursue our analysis of Chile's private pension system in this article in five distinctive ways. Importantly, the first section articulates an historical review of the development of Chile's private pension system, particularly the salient features of the 1981 pension reform which created it, and the nature of its core provisions, including private fund management, the DC principle, and the requirement for schemes to be fully funded (FF). In this section we also introduce our theoretical framework and argue that this reform was not the product of a neoliberal approach to retirement, but of a conservative approach that sought to make the pension system compulsory, limited the number and type of financial entities involved in the administration of pension funds, and created a privileged position for the pension fund administrators through a complex regulatory system. This privileged position has allowed the pension fund administrators to rip large profits, while pensions are insufficient and the role of the state supplementing those pensions continue to increase.

The second section evaluates the impact of the 1981 reform which introduced a pioneering DC system. In a DC system the employee contributes to his/her individual account at a set rate, and the contributions are invested and administered on the employee's behalf by a designated financial institution. A DC pension approach does not promise a specific amount of benefits at retirement, as it is the case in a defined benefit system, but the employee will ultimately receive the balance in the account, which is based on contributions plus or minus investment gains or losses and minus fees paid for the administration of the monies. In this section we argue that the impact of the DC pension approach has been largely negative for both the retirees and the state generating inadequate pension coverage, excessive administration costs and management charges, diminutive investment returns, and an approach to the regulation of pensions that has disadvantaged workers by giving substantial market privileges to the corporate actors responsible for managing the system.

The third section addresses the 2008 pension reform, focusing on the role of the state in supplementing, supporting, and subsidizing the private pension system. In particular, we highlight elements of the reform relating to pension coverage, including the treatment of independent workers (the self-employed), and the retirement prospects of women, who have been acutely disadvantaged in pension terms. Section four evaluates several of the provisions of the 2008 reform against a range of criteria. Drawing on some of the most recent data available, the fifth section appraises the effectiveness of current retirement provision in augmenting the retirement prospects of Chilean workers. Because the benefits of the 2008 reform were partial, a further round of pension reform is on the legislative horizon.

The paper concludes by arguing that in spite of attempts to improve the retirement benefits provided by the FF, privately administered pension system, the privately administered pension fund system has remained unchanged and the model continuous providing disproportionate benefits to the pension fund managers and insufficient benefits to the retirees. Thus, Chile provides a very useful example of a flawed pension model that should not be emulated by other countries seeking to reduce fiscal involvement in the provision of retirement benefits because it fails to reduce both inequality and poverty. 


\section{Chile's retirement system in historical perspective}

Chile, a country of almost 18 million people and with an economically active population (EAP) of about 8.5 million, was a pioneer in pension privatization and its 1981 reform inspired both the World Bank and other countries to recommend and pursue similar policies.

Between 1924 and the early 1970s, retirement provision in Chile was structured predominantly around a pay-as-you-go (PAYG) financed Common Fund system, which developed in a very amorphous and unique form. By 1973 it covered about $75 \%$ of the EAP through more than 600 small and 35 major funds, and through substantial legislation geared to provide special benefits to those interest groups that could exercise political and/or economic power (Borzutzky, 2002).

In the case of Chile, the development of what Mesa-Lago aptly called the "massification" of social security benefits in the mid-twentieth century was followed by a massification of privileges and exemptions that substantially distorted the basic notions of equality and universality that should be at the core of a retirement system (Mesa-Lago, 1976). As a result, the provision of social security became expensive for the state, the insured, and the employers; was suffused with administrative and financial inefficiencies; and was inherently unequal. In fact, the multiple funds reinforced patterns of socio-economic inequality present in wider Chilean society because although a minority of privileged workers received a wide array of generous benefits, the pensions received by the majority of the population were insufficient for their needs. Attempts to reform and rationalize the administrative and financial dimensions of the pension system during the Alessandri and Frei administrations (1958-1964 and 1964-1970) were frustrated by powerful interest groups and their representatives in the Chilean Congress (Borzutzky, 2002).

While it is clear that the social security system needed a major reform, including the elimination of the multiple funds and privileged pensions, it is not so clear that the system needed the reform that was introduced by the military dictatorship of Augusto Pinochet (1973-1989). As argued elsewhere, the 1980 social security reform was a bi-product of the institutional power and neoliberal ideas of the "Chicago Boys", General Pinochet's economic advisors (Borzutzky, 2002). The ideology of the free market and individualism expounded by the military dictatorship's policy-makers, supported by high levels of repression and the destruction of Chile's political institutions, produced a far-reaching transformation of the role of the state, its socio-economic policies, and the country's economy, and society. In the labor and social security areas, substantial reforms were developed and implemented by Labor Minister José Piñera. Piñera argued that the old system had failed to achieve its goals, and that instead of creating a more egalitarian society, it had created unjustifiable privileges and inequalities. The Chicago Boys engineered a radical overhaul of the social security system by replacing it with a privately administered, compulsory, FF, DC pension system. Reflecting its ostensible commitment to both the market and individualism, and its aim to reduce labor costs, the reform eliminated the portion of the social security tax paid by the employer. The newly created compulsory "savings/pension" scheme was to be privately administered, but supervised by the state. However, it is important to note that the state's supervisory role was created not to protect consumers, but to protect the interests of the corporate agents responsible for managing worker's pensions (Borzutzky, 2002). The transference of the administration to the private sector involved the creation of a new type of enterprise: The Administradoras de Fondos de Pensiones (Pension Fund Managing Corporations), or AFPs. The AFPs are the only entities empowered to administer the pension funds, are for-profit corporations, and charge commissions for the management of the individual accounts. 
Central to the FF, DC pension reform was the elimination of the principle of social solidarity and its replacement by the notion of individual responsibility - but in this case it was compulsory individual responsibility. Thus, the privatized scheme was made mandatory for all the workers who joined the work force after December 1981, while those already employed could choose between the PAYG Common Fund and the private system. In practice, younger workers and employees in the private sector moved in large numbers to the private pension arrangement because of the impact of a massive propaganda campaign launched by the government and the AFPs, and because of the sizeable reduction in contributions under the DC system. On the other hand, many workers in the public sector, and older workers, remained in the PAYG system. It is of course ironic that while the reform took place under a military regime that had adopted a free market mantra, those charged with the responsibility of upholding the Pinochet regime, the military and the police, retained their state-administered PAYG pensions that had existed since the 1920s.

The individual pension funds, or savings accounts, are financed by a $10 \%$ wage tax paid only by employees - employers and the state are exempt from contributing financially to workers' pensions under the private system. In addition, workers are permitted to make additional voluntary contributions above the mandatory $10 \%$, which are administered in separate funds established by the AFPs, with the sole purpose of managing voluntary contributions (Gobierno de Chile. Decree-Law 3500). From an administrative standpoint, privatization entailed the disappearance of the old funds and the creation of a unified administrative system under the Instituto de Normalización Previsional, renamed Instituto de Prevision Social (IPS) in 2008. The IPS administers the Bono de Reconocimiento, or Recognition Bond, which represents the amount of money accumulated in the PAYG system. These moneys are transferred to the individual account at the time of retirement. Other administrative units include the Superintendencia de Administradoras de Fondos de Pensiones, known today as Superintendencia de Pensiones, which is in charge of licensing, supervising, regulating, and dissolving AFPs.

Pensions are provided either directly by the AFP through programmed withdrawals, indirectly through an annuity bought from an insurance company with the funds accumulated in the account, or through a combination of the two. When the annuity option is chosen the accumulated funds are permanently transferred to an insurance company, which determines the amount of the pension, as well as funeral and survivors' benefits. The annuity must be inflation-protected and provide for survivors' benefits (Reyes \& Pino, 2006). When a programmed withdrawal is chosen, the pension is determined annually by the AFP on the basis of the affiliate's life expectancy and the assets' rate of return. If the retiree exhausts his/her account assets, he/she qualifies for a state-provided minimum pension (Asociación de AFPs, 2000, pp. 1 and 2). In the case of disability and survivors' pensions, the benefit is paid directly by the AFP.

The state also acquired the obligation to provide Minimum Pensions to those in the private pension system who did not have enough money saved to have a pension equal to the statutory minimum. To supplement and complement the pension system, the 1981 reform established a means-tested and parsimonious Welfare Pension for those who are below the poverty level and had not contributed to the system.

\section{The negative impact of the $\mathbf{1 9 8 0}$ reform}

The privatization of pensions affected the entire society as well as the state, but any benefits arising from the reform came to be distributed in a highly unequal manner. We now have more than 30 years of data on the socio-economic effects of pension privatization, and this leads to the conclusion that the FF, DC system is expensive, concentrates income in 
the hands of the Pension Fund Administrators, generates huge profits for the AFPs, is exclusionary, and discriminates against women (Borzutzky, 2002, 2008, 2011). Moreover, fiscal responsibilities for the Minimum Pensions and Bonos de Reconocimiento have created a persistent budget deficit which has been financed by taxes paid by all Chileans. This section develops an analysis of the impact of privatization up to 2007, which can be illustrated in six ways.

\subsection{Excessive management charges}

The reform promised an efficient pension market in which management charges, fees, and commissions would be determined by competition. However this promise, like many of the other promises made by the architects of the reform, has not been realized. The number of AFPs operating in the market declined substantially during the period 1980-2007 resulting in significant pension fund management industry concentration, and this has circumscribed competition and efficiency. Today, there are only six AFPs responsible for managing worker's savings, and although management charges have fluctuated, they have remained exceedingly high. A World Bank report estimated that pension fund administrators have retained between a quarter and a third of workers' contributions in the form of commissions, insurance, and other administrative fees since the inception of the system (Gill, Packard, \& Yermo, 2004). This is corroborated by Mesa-Lago who estimated that by 2008 the AFPS retained about $27 \%$ of the deposit (Mesa-Lago, 2014, p. 9). Privatization of pensions has led to a massive concentration of income in the hands of the AFPs (over $60 \%$ of GDP is controlled by the AFPs), while the profitability of the companies in the early years of the twentieth century was estimated to be over 50\% (Gill et al., 2004). Additionally, between 1993 and 1997, the rate of profits of the industry was double the rate of profit of any other industry in the country, but after 1998 this process became even more pronounced and the rate of profits of the AFPs reached annual rate of 53\% (Valdés \& Marinovic, 2005). The AFPs administrative charges are $89 \%$ more expensive than banks or private stock brokers charges (Valdés, 1999). The question of high profits is compounded by the lack of market competition and the fact that since its inception the number of AFPs has been reduced to five and that the three largest AFPS manage $86 \%$ of all the accounts (Mesa-Lago, 2014, p. 6).

We should also note that the imposition of management charges in the new privatized retirement system operated in a regressive way that penalized the poorest. As a percentage of the average salary, the value of the commissions decreased from $3.57 \%$ in 1982 to $2.43 \%$ in 2003 (Superintendencia de Administradoras de Fondos de Pensiones (SAFP), 2003, p. 9). However, the charges have been quite regressive and this has not changed. For instance, for an insured person with an income of about US $\$ 1609$, the administrative costs fluctuated between $25.6 \%$ and $37.9 \%$ of the deposit; while the cost for an insured person with an income of US $\$ 13,000$ fluctuated between $24.1 \%$ and $30.2 \%$ of the deposit (SAFP, 148, Dec, 1998, pp. 28-32). The FF system has also had a very powerful effect on the AFPs owners due to the massive transference of funds from the public to the private sector of the economy. By March of 2003, the combined amount of capital accumulated in the hands of the AFPs amounted to 55.77\% of GDP (SAFP, 2003, p. 5).

But however large Chilean pension fund management fees might appear to be, can we think of them as excessive? One way of addressing this is to compare management charges in Chile's private pension with those of other financial services and institutions. As suggested earlier, Chile has had the third highest level of charging for pension fund management among the mandatory DC pension schemes of Latin America. Other scholars of 
Chilean social security have concurred with our analysis. Valdés (1995) for example compares management charges in ten DC pension arrangements, and concludes that Chile belongs to the group of "expensive" countries - like us, he finds that it has been the third most expensive. In a more recent analysis, Valdés and Bateman (1999) compare management charges in the mandated DC pensions of Australia and Chile, and find that the latter has been up to $60 \%$ higher. They estimate that Australian plan participants have paid $30 \%$ less in management charges over the entire accumulation period. Similar findings can be generated if we broaden our analysis to include other types of financial institutions. According to a study of Chile's privately administered retirement system, AFP management charges have been up to two-thirds higher than the fees imposed by the country's banks for administering savings and on-time accounts (Hyde, Dixon, \& Drover, 2006). For the period 1997-1998, Valdés and Bateman show that AFP charges were up to $67 \%$ higher than fees for the management of savings accounts, and professional asset management services elsewhere in the financial sector, which were less exposed to intrusive state regulation. This evidence gives some credibility to the belief that Chilean pension fund management charges during the period of our analysis were "excessive".

\subsection{Diminished coverage}

There has been considerable discussion about the extent of the coverage provided by the FF, DC system since its inception. Data for 2003 shows a marked decline in coverage, since the AFP system was covering only $52.5 \%$ of the EAP, with another $2.72 \%$ still enrolled in the common fund system. By 2007 , about $50 \%$ of the population was excluded from the system, and a large portion of those who contributed were not be able to save enough to obtain the equivalent to a minimum pension forcing the state to fund those pensions through its Minimum Pension program. Moreover, the pension system had left out a large portion of the population including the self-employed and all those Chileans that have either been unemployed, or had a part time employment during their active life. Additionally, the privately administered pension system was seen as discriminating openly against women because women live longer than men, their salaries are about $30 \%$ lower than the salary of their male counterparts, and they contribute less because of child rearing and other family responsibilities (Arenas de Mesa \& Montecinos, 1996). As a result, the data shows a dismal situation in terms of the number of female contributors, the number of women accessing FF pensions, and the replacement ratio of their pensions. By 2007 , only $39 \%$ of women (versus $61 \%$ of men) were actively contributing to a pension and only $54 \%$ of all retirees were women as opposed to $69 \%$ of men (Mesa-Lago, 2014, p. 6). While the question of replacement ratios is complex and it will be addressed later, it is important to note that the replacement ratio for women is about $35 \%$ while the replacement ratio for men is about $46 \%$ (Mesa-Lago, 2014, p. 6).

\subsection{Sub-optimal investment performance}

Even though the fees have been higher than in comparable financial services and institutions, Chile's pension fund management charges could have been deemed justifiable if it could be demonstrated that plan participants were able to benefit from superior investment returns by paying more. Scholars of Chilean social security who endorse the privately administered retirement system have not been slow to highlight the impressive investment returns that have been generated by AFP involvement in asset allocation. For one survey of Chile's fund managers, the average investment return for the period 1981 to 2000 was 
$11 \%, 3.8 \%$ higher than the average interest rate for bank deposits (Acuña \& Iglesias, 2001). Nevertheless, there is substantial evidence to suggest that the investment performance of Chile's fund managers has been sub-optimal, falling short of the returns that would be necessary to justify their considerable income streams. In this respect, we should recall that the ostensible purpose of management charges is to render payment for the service of generating investment-driven increments to the value of retirement assets, which means that it is returns to plan participants that ultimately count. Much of the evidence around net returns - which are a function of investment returns and management charges - suggests that the performance of the AFPs during the first two decades of the 'private' system was rather less impressive. When returns are estimated in this way, they are 'more than halved from what has been reported by the AFPs and conservative pundits' (Leiva, 2006, p. 7). According to one authoritative study (Acuña \& Iglesias, 2001), the AFPs generated an average net return of $5.1 \%$ during the first two decades; while Kay (2003) estimates average net returns of $0.3 \%$ for the period 1982-1986, and 2.1 for 1991-1995. Even during the "good times" of the first two decades then, there is evidence that might lead us to question the assertion that high management charges were grounded in superior investment returns.

In large measure this reflects the substantial re-composition of Chile's pension fund management industry. As highlighted earlier in this article, its remarkable and sustained concentration has eroded market competition, accentuating the tendency towards correlated trading. Not surprisingly there is evidence to suggest that regulatory-induced herding has impacted negatively on performance, generating a downward trend in realized investment returns. Looking only at the six largest AFPs, the evidence highlights an inverse relationship between the degree of concentration in the pension fund management industry and its investment performance. During the first fourteen years, when the number of AFPs grew substantially, monthly investment returns for all six fund managers ranged between $-1.8 \%$ and $8.6 \%$, and negative returns were uncommon (thus a period marked by more fund managers and better returns); during the period 1995-2000, when concentration was starting to become more salient, investment returns ranged between $-6.4 \%$ and $6.6 \%$ and negative returns were common (growing concentration, diminishing returns); but during the period 2001-2004, when industry concentration was most prominent, investment returns ranged between $-1.6 \%$ and $2.5 \%$, and the incidence of negative returns was high (high concentration, low returns) (Borzutzky \& Hyde, forthcoming).

\subsection{Insufficient benefits}

Contrary to the expectations created by the architects of the program, the value of the pensions offered by the FF, DC system has not changed dramatically either. In 2001, the value of an average FF pension was $12 \%$ higher than the value of a pension provided by the common fund system, but in the case of disability pensions the pension provided by the common fund system was $23 \%$ higher than the pension provided by the FF system (SAFP, 2001, p. 199). A comparative 2014 study done by the Instituto Libertad y Desarrollo, a right of center think tank, which included 976,000 retirees concludes that the AFPs pay an average old age pension of about US \$354, while the Instituto de Prevision Social in charge of paying the pensions of those who remained in the PAYG system pay an average old age pension of US \$390. It is important to keep in mind that while the AFP affiliates' total contribution liability $13 \%$ of the wages (basic $10 \%$ of the wages plus additional contributions for special programs), the contribution made in the public system amounts to $20.7 \%$ (El Mercurio.com, July 6, 2014). 


\subsection{Income inequality}

What has been the pension system's impact on inequality and income distribution? The transition to democracy has brought about a massive decline in poverty, from over $50 \%$ of the population in 1990 to $14.4 \%$ in 2013 . However, the country's distribution of income remains highly unequal and unchanged. As a result, the Gini Coefficient declined slightly from 0.53 in 1990 to 0.50 in 2013 (Encuesta Casen, 2013). Moreover, when the Gini coefficient is used to measure the distribution of pension income, a 2005 government report established that "the distribution of retirement income is much more unequal than the distribution of active life income for the same cohort ... . The same can be said for the level of minimum pension guaranteed by the state" (Reyes \& Pino, 2006). Thus, the Gini Index for retirement income is higher than the actual Gini Index of about 0.52. Moreover, a 2013 Organization of Economic Cooperation and Development (OECD)' pension study reaffirms the negative redistributional impact of the pension system through its progressivity index. According to this index, a perfectly progressive system gets a score of a 100 while a system that does not have any impact on progressivity gets a 0 . Chile's index is 27.9 , a number well below 39 which is the average for all OECD countries and 82 which is the average for Anglophone countries (OECD, 2013, Pensions at a Glance). Thus the OECD study confirms that the current pension system does not have a positive impact on income redistribution and in fact reinforces the skewed distribution of income present in the Chilean economy.

Turning specifically to the issue of women's pensions it is important to note that female labor force participation increased from $35 \%$ in 1990 to $55 \%$ in 2011, but it is still $7 \%$ below OECD and Latin American averages. Moreover, there was an increase of the share of women's participation in the labor force from $30 \%$ in 1990 to $40 \%$ in 2011 , in part due to the decline in male participation in the labor force. Lastly, the gender wage gap defined as the ratio of the male to female wages, declined from 1.4 to 1.2 during the same period. This gap is close to OECD and Latin American averages (IMF, 2014).

Women's participation in the DC system and gender inequalities in retirement income can be illustrated starkly with reference to evidence regarding replacement rates. In practice, the replacement ratio can be calculated either on the bases of the last wage or on the bases of the average wage received in the last ten years. A government study looked at retirees with more than 30 years of savings and estimated that the ratio was of $66 \%$ for men and $42 \%$ for women based on the wages obtained in the ten years prior to retirement. While a study done by OECD established that the net ratio -after paying taxes- was of 52\% for men and $42 \%$ for women (El Mercurio.com, October 20, 2014).

In brief, by 2006 it had become clear that many Chileans were dissatisfied with the pension system because of the high administrative costs and the low replacement ratios. Dissatisfaction with the system became clear in 2005 as the first group of retirees began to collect pensions. These retirees, and others that followed them, felt cheated by the system and began to lobby for pension reform through the Association of Pension Damaged People which quickly grew to about 150,000 members. In fact, the dissatisfaction with the system not only served as the foundation for an anti-DC pension group, but also coined a new term which is now widely used in Chile: daño previsional, or pension damage (Delgado, 2007). More recently, in 2011, the AcusaChileAFP lobby was formed to criticize the existing policies and demand major pension reforms (AcusaChile). This dissatisfaction has been confirmed by the Bravo Commission' survey conducted in 2014 which revealed that $72 \%$ of those polled believed that pensions will improve only if there is a total change in the AFP system and that $66 \%$ considered that the low pensions are responsibility of the AFPS (Cambio 21) 
Lastly, it had also become clear to experts and government officials that reforms were needed because of a growing budget deficit resulting from the government obligation to pay an ever larger number of minimum pensions. This deficit has remained close to $5 \%$ per year (Melguizo, Muñoz, Tuesta, \& Vial, 2009 [BBVA working papers, 2009]).

\subsection{Fiscal impact}

The operation of the private pension system during the period 1980-2007 also impacted adversely on the fiscal capacity of the state. The creation of the fully funded, DC system did not reduce, but simply changed the role of the state. In reality, the state continued to have a large number of pension responsibilities with regard to retirement income protection, since it was paying the pensions of those who stayed in the Common Fund system; was paying the Recognition Bond at the time of retirement of those who began in the Common Fund system and then transferred to the FF system; and it was paying the Minimum and Welfare Pensions. The two most expensive elements of the private pension system were the payment of Recognition Bonds, which were expected to diminish over time, and the payment of Minimum Pensions, which were expected to increase in the future. As a result, these responsibilities have produced a budget deficit close to $5 \%$ of GDP per year (Borzutzky, 2002, Ch. 7, BVA, p. 13).

\section{New horizons? The 2008 reform}

Between 1990 and 2005, Chileans elected to the presidency members of the center-left Concertación coalition formed by Christian Democratic, Socialist and other smaller parties. Reflecting the negative impacts of privatization, Socialist presidential candidate Michelle Bachelet promised to reform the retirement system and shortly after her inauguration in January 2006, she established the Marcel Commission to study the pension system and propose reforms. The overall goals of reform, as articulated by the Commission's report presented to President Bachelet in July 2006, were to move the country toward the universalization of benefits, augment the pension system's replacement ratio from $45 \%$ to the OECD average which is $60 \%$, and reduce the variability of the replacement rate due to differences in the density of contributions and the different profitability of the accounts associated with different socio-economic and income groups. The reform also aimed at eliminating the risk of old age poverty by strengthening both the Welfare and Minimum Pensions, and proposing the creation of a strong and well integrated Solidarity Pillar. The goals of the Solidarity Pillar were to protect and integrate low income groups into the pension system, provide mechanisms to increase the density of contributions, develop new approaches geared to increase competence among the AFPs, increase the funds' rates of return, increase transparency in the management of the pension funds, and strengthen the voluntary pillar by providing new benefits to those who manage to have additional savings (Consejo Reforma Previsional, pp. 98-101).

Another important problem tackled by the report, and subsequent legislation, was the low level of coverage and the low density of contributions, especially among lower income groups. In fact, 28 years after implemented, the FF, DC scheme covered only about $60 \%$ of the population and had systematically excluded the majority of the independent workers who, given the volatilities and lack of contractual arrangements in the Chilean labor market, comprised a large portion of the population. Moreover, the same volatile labor market conditions had generated a low density of contributions (Report Comisión Marcel, p. 111). Months of Congressional discussion and multiple legislative maneuvers resulted in 
a negotiated reform bill. In January 2008, the Chilean Congress approved not all, but some of the most important proposals of the Marcel Commission.

The most important accomplishment of the 2008 legislation (Gobierno de Chile. Law 20255) was to guarantee a Basic Solidarity Pension (PBS) to all Chileans over 65 years old who had never contributed to the pension system. By 2013 the value of the PBS amounted to US \$160 (Gobierno de Chile. Subsecretaría de Previsión Social). The state also guarantees a Supplementary Contribution (Aporte Previsional Solidario, APS) to those who have insufficient contributions to finance their retirement benefits. To qualify for the state contribution the affiliate must have made contributions to an AFP, but the value of the accumulated funds should generate a pension that is less than US \$520 (Superintendencia de Pensions, Aporte Previsional Solidario de Vejez). This benefit is calculated on the basis of accumulated savings and is expected to provide pensions equivalent to $60 \%$ of those in the lowest income groups (Gobierno de Chile. Reforma Previsional Gobierno de Chile). The government also provides a Basic Disability Pension to those covered by the PBS. In brief, the state acquired a number of new responsibilities and the most important of those is the PBS that was designed to reduce old age poverty by expanding coverage and providing a pension to workers that for a variety of reasons had never established a pension account in an AFP. Most favored by the PBS are workers who have been in and out of the labor market, temporary and independent workers, and women. It is estimated that $60 \%$ of the solidarity pensions will be devoted to women. Those who started to save, but did not accumulate sufficient assets receive the APS and the state also provide disability pensions to all those covered by the PBS and the APS.

In order to augment the value of women's pensions, the 2008 law mandates 18 months of state contributions per child. The state contribution is based on a minimum salary. Although the money is not deposited into the account until the woman turns 65 , the contribution begins to generate interests from the moment the child is born. Moreover, because women do not use the disability and survival pensions as much as men, the part of the deposit that is not used for these items is deposited directly in the woman's account. The goal here was to increase women's pensions and to reduce the existing pension gender gap. The architects of the 2008 reform argued that as citizens, women are entitled to the same pension benefits as men, and that the state is obligated to rectify inequalities that result from gender differentials in labor force participation (Comisión Marcel Report, pp. 118-120).

Regarding independent workers, the legislation introduced a ten year transitional period to integrate them into the pension system. By the end of this period the independent workers should be contributing and receiving the same benefits as dependent workers. The entrance of new independent workers into the system is regulated by the state through a "bidding system" according to which every year the state groups those interested in joining the pension scheme into "packets" and the AFPs have to offer formal bids to capture the packet. The bids must specify commissions and other administrative costs. Once an AFP obtains a "packet" of insured, it cannot increase the commissions for at least 18 months. In order to encourage expansion of the pension system and young workers contributions, the government also subsidizes the pensions of workers between 18-35 years of age with an income that is less than 1.5 of the minimum salary.

The 2008 law also favors middle income groups through the creation of a system of Voluntary Pension Savings (Ahorro Previsional Voluntario). These voluntary savings enjoy a number of tax benefits and can be deposited not only with AFPs, but also in a number of other financial entities including insurance companies, mutual funds and banks among. The goal here is to incentivize savings and allow the individual a wide variety of both institutional and risk options (Superintendencia de Pensiones, El Sistema Chileno de Pensiones, 2014 p. 99). 
From a financial standpoint, the 2008 reform was more expensive than any other social program created in Chile between 1990 and 2010. According to Hujo and Ralli (2014), the fiscal costs associated with the reform were estimated to increase from $0.27 \%$ of GDP in 2009 to over $1 \%$ in 2025 (p. 14). The 2008 legislation established that the reforms' costs were to be financed through the Pension Reserve Fund established in 2006. As a result of the 2008 reform, by December of 2012 the government had provided 406,674 PBS pensions which amounted to about $35.2 \%$ of all the pensions granted (Hujo and Rulli, p. 18).

\section{Impact of the 2008 reform}

The most critical impact of the 2008 reform has been the introduction for the first time since 1980 of a social component into the pension system through the addition of the Solidarity Pillar, or state financed pillar which supports the expansion of pensions to lower income groups, young workers and women. Moreover, the incorporation of new workers through a system of bids seems to have led to a reduction in the administrative costs for that group of workers and the strengthening of the voluntary savings component, or third pillar of the system, fostering an increase in voluntary savings.

As well as these beneficial impacts, the state has gained because in the long run the addition of the Solidarity Pillar will imply a reduction of the fiscal costs. As mentioned above, the transition from the PAYG to the privatized system entailed a number of fiscal costs including paying for the Bono de Reconocimiento and the Minimum and Welfare Pensions, as well the payment of the pensions of those who chose to remain in the PAYG modality. These transition costs have been sizeable and have evolved over time. Transition costs amounted to $7.6 \%$ of GDP in the early 2000 and had declined to about 5\% in 2008 and $4.7 \%$ in 2010 , but where expected to remain high given the increase in the state's payment of Minimum Pensions. Estimates made by the Marcel Commission and also by Carmelo Mesa-Lago show a reduction of transition costs as a result of the 2008 reform. The law also created a reserve fund to finance the new benefits (Mesa-Lago, 2014, pp. 17-20).

While the 2008 law represents a step in the right direction regarding expansion of pensions to lower income groups and women, improving the chances that future lower income retirees have to obtain higher pensions and higher replacement rates, and reducing the state's fiscal burden, there were important recommendations made by the Marcel Commission that were not included in the legislation due to opposition from the political right and the AFPs. Among them were the incorporation of banks into the Pension Fund Administration business in order to introduce competitiveness in the pension administration business and the creation of a state managed AFP, both having the potential of expanding competition and lowering costs. Because these recommendations were not included in the final legislation, and because there is no mechanism in place to reign in the administrative charges, the reform does little to change the monopolistic nature of the AFPs, left the question of the high commissions or administrative charges untouched, and failed to resolve the problem of the insufficiency of pensions due to high administrative charges. These problems are being tackled by yet another reform commission -the Bravo Commissioncreated by President Bachelet in early 2014.

\section{The Chilean retirement system today}

Finally, we turn to the performance of Chile's retirement system today. This discussion highlights several of the problems faced by the pension system and the retirees, and analyzes the solutions proposed to address these issues. 
In 1973 Chile's social security system covered about $73 \%$ of the EAP and by late 2014 the combined FF pension scheme and the remnants of the old PAYG system covered the same $73 \%$ of the EAP. A total of 9.7 million Chileans are registered in one of the six AFPs, but only 4.9 million of those are active contributors. The total savings accumulated in the hands of the pension fund administrators amounted to US $\$ 163,196$ million or about $69 \%$ of the Chilean GDP in 2013. The data also shows that the AFP system has provided pensions to 998,457 retirees with an average pension of about US \$400 monthly (El Mercurio.com, July 23, 2014).

As highlighted above, estimating replacement rates is complicated given the different measurement that can be used. These difficulties also reflect the impact that the density of contributions can have on any measurement. In consequence, our assessment of income replacement here relies on a range of ratios. Thus, today replacement rates range from $11 \%$ to $55 \%$ of the wages for men and from $8 \%$ to $40 \%$ for women. The variability or range is determined by the number of years of active contributions and the consistency - or density - of contributions made into the savings account. In practice, a woman who had a full active life and never missed a month of deposit will get a pension equal to $40 \%$ of her wages, and a man in the same circumstances will get a pension equal to $55 \%$ of his wages. The data also shows that on average men make deposits for about 25 years out of a 45 year working life while women register about 15 years of deposits out of 35 year work life. As a result, the replacement rate for women is a lot smaller. A study by the Piñera administration compiled in what is known as the Pension White Book estimates that more than half of retirees have pensions that are less than $48 \%$ of the average wage received in the last ten years of active life (Jimeno Ocares, 2014). By comparison, average replacement rates in OECD countries amount to $65.8 \%$.

Between 1991 and 2009 the average old age pension increased by $11 \%$, but we should note that the real growth of an old age pension was of about $2 \%$ per year; that there was no real growth if the retiree had to take early retirement, or retired due to disability; and that in the cases of widows and children pensions, there was a $4 \%$ real growth of pensions. Alongside this modest performance with regard to benefit entitlements, AFP income generated by management charges amounted to US \$766 million by September of 2013 (El Mercurio.com, January 27, 2014). As for the Solidarity Pillar established in 2008, and fully implemented in 2012, the costs to the state were equivalent to US \$1621 million per year. The Basic Solidarity Pension amounts to about US $\$ 180$ and it is given to men and women over 65 years of age that are among the poorest $60 \%$ of the population (Jimeno Ocares, 2014).

As this data suggests, although the 2008 reform managed to expand the coverage, it did not substantially increase the value of the pensions provided by the AFPs. As a result, in early 2014 the newly reelected President Bachelet faced a multitude of claims and popular dissatisfaction with the state of the pension program. The government addressed this disenchantment by forming a second commission, charged with examining the nature of the system's problems, and with identifying appropriate solutions. The commission comprised of 23 experts, and officially known Comisión Asesora Presidencial sobre el Sistema de Pensiones (2015), or Pension System Advisory Presidential Commission, generated feedback from 78 different national and international experts over a 6 month period. Its central mission is to tackle the never resolved problem of pensions' insufficiency, replacement rates that are well below the expectations of the current and potential retirees, and the high administrative costs. A survey conducted by the Bravo Commission showed that over $70 \%$ of those interviewed do not approve of the current system.

As understood by the Commission's members and their advisors, low pension and replacement rates result from a number of factors including high administrative charges, 
insufficient contributions (the mandatory deposit is of only $10 \%$ of the wages), the lack of employer contributions, and inequalities in the minimum retirement age (60 years for women and 65 years for men). In order to address these problems, the Bravo Commission considered a variety of proposals including allowing banks and other financial institutions to administer the pension funds, and the creation of a state-owned and administered AFP in order to increase competitiveness and reduce administrative charges - the same solutions proposed, but never adopted in 2008. According to its proponents, a state-administered AFP will provide Chileans with one more savings option which could be very attractive to independent and low income workers, and would allow for an increase in the density of contributions. A prominent expert on Chilean pensions, Salvador Valdés, proposed the establishment of not-for-profit administrators, including unions, in order to reduce costs and capture the independent workers (El Mercurio.com, October 7, 2014). Others have criticized the proposal for a state-owned AFP on several grounds: it will not generate higher returns; it will be difficult to sustain unless it generates profits for the state; the state will have to subsidize its operations; it could entail a violation of banking laws because it would have to be linked to the State Bank, Banco del Estado, and its funds will be used for political purposes, among others (El Mercurio.com, April 19, 2014).

Regarding contributions, there is a belief both among the AFP administrators and experts that a $10 \%$ contribution is inadequate and that what is needed is a minimum contribution of at least $13 \%$ to be able to generate a sufficient pension. Another proposal involves the establishment of a mixed contributory system which will include an increase in the compulsory savings rate to about $15 \%$ of the wages, with the additional $5 \%$ deposited in a common fund that can be used by current retirees to increment their pensions.

The AFPs on their part are proposing that Chileans postpone their retirement age, which currently is 65 years for men and 60 for women. According to an estimate made by the Bravo Commission, if a woman postpones her retirement age by 5 years she can increase her pension by $40 \%$ (Bravo Commission, Final Report). To placate a very irate public which is quite critical of the management of the funds, the AFPs proposed that if the affiliate postpones the retirement, the AFP would not charge management fees for the years worked beyond the statutory minimum. The pension fund administrators are also arguing in favor of an increase in the contributions because the current $10 \%$ was established when life expectancy in Chile was $40 \%$ lower. They have also proposed to augment the voluntary savings and provide pension education to all Chileans (El Mercurio.com, March 27, 2014).

Lastly the pension management institutions have proposed to increase the employers' contributions to the retirement program (El Mercurio.com, June 20, 2014). The question of employer's contributions is often the last to be discussed, but not one to be ignored because Chilean employers make the lowest contribution to their employees' retirement among all countries with a FF-DC system according to data provided by International Federation of Pension Fund Administrators. In Chile, the employer only contributes $1.26 \%$ of the taxable wage, but rather than financing pensions, it pays for the Disability and Survival Insurance Program which has been responsibility of the employer only since 2011. In other FF systems the employer contribution ranges from $2.8 \%$ in Bulgaria to $12 \%$ in Colombia. Compared to other OECD countries, Chilean employers rank last, while Brazil, Italy, Portugal and Spain top the list with a $20 \%$ employer contribution. While it is unclear how much the employer should contribute in a FF program, the estimates range from $2 \%$ to $5 \%$ of the taxable wage. As expected, representatives of the business community and right wing think tanks argue that any increase in the employer's tax will lead to a reduction of wages (El Mercurio.com, June 24, 2014). 
The Bravo Commission was expected to present its report to President Bachelet in January of 2015, but it has already been postponed until mid-2015. Once the report is presented and approved by the President, it has to be turned into a bill and sent to Congress. It is expected that right wing politicians will intensely oppose both the establishment of a state-owned AFP and any increase in employers' contributions.

\section{Conclusion}

It is clear then that in Chile, as elsewhere, the design of pensions and the distribution of retirement income, including the degree of poverty, are closely related. The privatization of pensions was justified ideologically in terms of the normative repertoire of neoliberalism, which insists that the free market generates better outcomes for workers than the state ever could. This approach to pension reform has been pursued in several national jurisdictions across Latin America and Eastern Europe, as well as in some Western European countries, and is arguably the dominant pension reform model of the early twenty-first century. And yet our analysis of Chile here suggests that we should be cautious about embracing it.

A salient set of issues in Chile's DC pension arrangement concerns excessive management charges, and the enormous revenue streams that have been enjoyed by the country's pension fund managers. Moreover, a close analysis of the relationship between the AFPs and the state indicates that the state redistributes resources toward the AFPs, and has been subsidizing the private sector both before and after the 2008 reform. Prior to the 2008 reform, this subsidization was comprised mainly of paying for an ever growing number of Minimum Pensions, which led in part to the 2008 reform as fiscal deficits continued to increase. After the 2008 reform, the state has expanded its subsidizing role, because it absolves the AFPs of any responsibility in regard to both adequate performance and high commissions. Thus, while many are satisfied with the positive social impact of the Solidarity Pillar, we argue that the provisions of the 2008 reform support the private system in a myriad of ways, allowing the AFPs to charge high administrative fees, while failing to generate satisfactory rates of return for their customers. Moreover, over the long term, the architects of the 2008 reform have favored the AFPs by facilitating an expansion of the FF scheme to independent and young workers, and by subsidizing contributions for women's pensions.

The 2008 reform was a step in the right direction as it tried to rectify some of the diswelfares of privatization, in particular by universalizing opportunities to accumulate rights to a retirement income, including the provision of special benefits for women, the selfemployed and the poor. The reform reduced discrimination against women, expanded coverage to the lowest income groups and independent workers, and created positive incentives for young and middle income workers to save for their retirement. To the extent that these reforms have operated as a complement to the privatized system, however, any equitable impact has been limited. Greater equity will be realized only by expanding the role of employers, and making the AFPs more accountable both in terms of charges and profits.

As for the impact of the public pensions or the PBS on poverty, the effects have been severely limited by the low value of the PBS which is only about US $\$ 160$ per month. While, policy-makers argued that the US $\$ 160$ are much better than nothing, this very small amount does not contribute to a reduction in poverty in any meaningful way, and poor pensioners have rightly argued that the amount provided is entirely inadequate given Chile's high cost of living.

In conclusion, while the pension policies have reinforced both the concentration of income and profits in the hands of six administrators, it has so far failed to have a positive 
impact on poverty, except in those areas where there are benefits paid directly by the state. In a PAYG system the transference of resources often serves as a redistributive mechanism, especially when employers and the state supply additional funds to the retirement of those in the lower income groups. However, in a FF-DC system there is no redistributive effect and at least in the case of Chile the system has been exclusionary both in terms of gender and income. Lastly our lengthy discussion on replacement rates sends another devastating message because even for those who have participated in and contributed to a private pension the retirement pension is inadequate.

In brief, the 35 year experience with a FF, DC model in Chile send clear messages about the dis-welfares produced by the model and provide a number of powerful reasons to argue that governments elsewhere who are intent on pursuing the Chilean model as a basis for pension reform should give these issues serious consideration before they are tempted to pull the privatization trigger.

\section{Disclosure statement}

No potential conflict of interest was reported by the authors.

\section{Notes on contributors}

Silvia Borzutzky is Teaching Professor of Political Science at Carnegie Mellon University's Heinz College of Public Policy and Management.

Mark Hyde is a Reader in Work and Pensions at Plymouth University, and Director of Pensions Worldwide.

\section{References}

Acuña, R., \& Iglesias, A. (2001). Chile's pension reform after 20 years. Working paper 0129. Washington, DC:The World Bank.

AcusaChileAFP. http://acusachile.blogspot.com/2011/11/nace-acusa-afp-chile.html.

Arenas de Mesa, A., \& Montecinos, V. (1996). The privatization of social security and women's welfare: Gender effects of the Chilean reform. Latin American Research Review, 34, 37-38.

Borzutzky, S. (2002). Vital connections: Politics, social security, and inequality in Chile. Notre Dame: Notre Dame University Press.

Borzutzky, S. (2008). Social security privatization and economic growth. In J. Midgley \& K. Tang (Eds.), Social Security, the economy and development (pp. 111-136). Hampshire: PalgraveMcMillan.

Borzutzky, S. (2010). Pension market failure in Chile: Foundations, analysis and policy reforms. In M. Hyde \& J. Dixon (Eds.), Comparing how various nations administer retirement income: Essays on social security, privatization, and inter-generational covenants (pp. 197-216). Lewiston, NY: Edwin Mellen Press.

Borzutzky, S. (2011). Reforming the reform: Attempting solidarity and equity in chile's privatized social security system. In R. Hoefer \& J. Midgley (Eds.), Journal of policy and practice, special issue: poverty, income and social protection: International perspectives, 11(1), 77-91.

Borzutzky, S., \& Hyde, M. (Forthcoming). Chile's 'neoliberal' retirement system? Concentration, competition and economic predation in 'private' pensions, poverty \& public policy. In R. Hormazábal (Ed.), El dogmatismo liberal y la influencia del dinero nos niegan pensiones dignas (Cambio 21). Retrieved from http://www.cambio21.cl/cambio21/site/artic/20150921/ pags/20150921172616.html

Comisión Asesora Presidencial sobre el Sistema de Pensiones (aka Comisión Bravo). (September 2015). Informe final. Retrieved from www.comision-pensiones.cl/Documentos/GetInforme

Consejo Reforma Previsional. Comisión Marcel, Informe Final, 98-101. Retrieved from http://www. google.com/url?sa $=\mathrm{t} \& \mathrm{rct}=\mathrm{j} \& \mathrm{q}=\&$ esrc $=\mathrm{s} \&$ source $=$ web\&cd $=8 \& \mathrm{ved}=0 \mathrm{CF} 0 \mathrm{QFjAH} \& u r l=$ http $\% 3 \mathrm{~A} \% 2 \mathrm{~F} \% 2 \mathrm{Fdialnet}$.unirioja.es\%2Fdescarga\%2Farticulo\%2F2375839.pdf\&ei = bhG8VM 
VO67asASI-YHwDg\&usg = AFQjCNGiACwobvyT3n6O8LbB5Auu_GOgow\&sig2 = clsxRGz RTuj-X0yFVYjdEw\&bvm = bv.83829542,d.cWc

Delgado Lilian. (2007, January 9). Trabajadores debatieron en torno a la reforma y dano previsional en la UACH, Noticias UACH. Retrieved from http://noticias.uach.cl/principal.php?pag = noticiaexterno\&cod $=8777$

El Mercurio.com. (2014, January 27). Diferencias sobre \$300 mil al año hay entre AFP más barata y la más cara. Retrieved from http://www.economiaynegocios.cl/movil/iphone.asp?id=1165611.

El Mercurio.com. (2014, April 19) Los argumentos a favor y en contra para la creación de una AFP estatal. Retrieved from http://impresa.elmercurio.com/pages/LUNHomepage.aspx?BodyID $=2 \&$ $\mathrm{dt}=2014-4-19$

El Mercurio.com. (2014, March 27). Las AFP no fuimos suficientemente categóricas para alertar los cambios que venían.

El Mercurio.com. (2014, June 20). Las AFP proponen veinte ideas para mejorar pensiones e incentivar postergación de retiros.

El Mercurio.com. (2014, June 24). Propuestas de la CPC y la Asociación de AFPs a la Comisión Bravo insisten en necesidad de mayor contribución.

El Mercurio.com. (2014, July 6). 700 mil personas siguen recibiendo su jubilación del IPS: Pensiones del sistema antiguo son 45 percent más bajas que las que entregan las AFP.

El Mercurio.com. (2014, July 23). Número de nuevos pensionados por año crecerá más Del doble entre 2015 y 2020.

El Mercurio.com. (2014, October 7). Salvador Valdés plantea crear AFPs sin fines de lucro y permitir retiros de dinero a afiliados.

El Mercurio.com. (2014, October 20). Qué porcentaje representa la pensión respecto de los salarios de las personas en su vida laboral: Definición de la tasa de reemplazo de las pensiones sería un tema clave en el primer informe que prepara la Comisión Bravo.

Encuesta Casen. (2013). Ministerio de desarrollo Social, Gobierno de Chile. Retrieved from http:// www.ministeriodesarrollosocial.gob.cl/resultados-encuesta-casen-2013/

Gill, I., Packard, T., \& Yermo, J. (2004). Keeping the promise of old age income security in Latin America: A regional study of social security reform. Washington, DC: World Bank.

Gobierno de Chile. Decree Law 3500. Retrieved from http://www.leychile.cl/Navegar?idNorma $=7147$

Gobierno de Chile. Law 20255. Retrieved from http://www.leychile.cl/Navegar?idNorma $=269892$

Gobierno de Chile. Subsecretaría de Previsión Social, Pensión Básica Solidaria. Retrieved from http:// www.previsionsocial.gob.cl/subprev/?page_id $=7430$

Gobierno de Chile. Superintendencia de Pensiones, Aporte Previsional Solidario de Vejez. Retrieved from http://www.spensiones.cl/portal/orientacion/580/w3-article-5786.html

Gobierno de Chile. Reforma Previsional Gobierno de Chile. Retrieved from http://www.spensiones. $\mathrm{cl} /$ portal/prensa/579/w3-article-4193.html

Gobierno de Chile. (2014). Superintendencia de Pensiones, El Sistema Chileno de Pensiones (p. 99). Retrieved from http://www.google.com/url?sa $=t \& r c t=j \& q=\& e s r c=s \&$ source $=$ web\&cd $=1 \&$ ved $=0 \mathrm{CB} 4 \mathrm{QFjAA} \&$ url $=\mathrm{http} \% 3 \mathrm{~A} \% 2 \mathrm{~F} \% 2 \mathrm{Fwww}$.spensiones.cl $\% 2 \mathrm{Fportal} \% 2 \mathrm{Finformes} \% 2 \mathrm{~F} 58$ $1 \% 2$ Farticles-7206 libroVIIedicion.pdf\&ei $=$ n9C6VNSwKcbmsATHyILgDg\&usg $=$ AFQjCN EzavBknLapXycpY̌24b95w-7yq22w\&sig2 = I8errmblEcrif9aUjx-jpw\&bvm = bv.83829542,d. $\mathrm{cWc}$

Hujo, K., \& Ralli, M. (2014). The political economy of pension re-reform: Toward more inclusive protection. United Nations Research Institute for Social Development, Social Policy and Development (2000-2009). Retrieved from http://www.unrisd.org/80256B3C005BCCF9/ search/13C947C84 CC4FAFFC1257CAF004697A0?OpenDocument

Hyde, M. \& Dixon, J. (2009). Individual and collective responsibility: Mandated private pensions in comparative perspective. Journal of Comparative Social Welfare, 25(2), 119-128.

Hyde, M., Dixon, J., \& Drover, G. (2006). The privatization of mandatory retirement income protection: International perspectives. Lewiston, NY: Edwin Mellen Press.

International Monetary Fund. (2014, July). IMF Country report 14/219, Chile. Selected issues paper (p. 12). Washington, DC. Retrieved from https://www.imf.org/external/ .../cr14219.pd.

Kay, S. J. (2003, March 27-29). State capacity and pensions. Paper presented at the LASA XXIV International Congress, Dallas.

Jimeno Ocares P. (2014, October 26). Pensiones: Los cambios que estudia la Comision BravoLa. Tercera, Santiago. 
Leiva, F. (2006, May/June). Chile's privatized social security system: Behind the free market hype, a scam. Connections, pp. 1-13.

Melguizo, A., Muñoz, A., Tuesta, D., \& Vial, J. (2009). Pension reforms and fiscal policy: Some lessons from Chile. BBVA Working Papers. Economic Research Department, No 0915.

Mesa-Lago, C. (1976). Social security in Latin America: Pressure groups, stratification and inequality. Pittsburgh: University of Pittsburgh Press.

Mesa-Lago, C. (2014). Reversing pension privatization: The experience of Argentina, Bolivia, Chile and Hungary. ESS Working Paper 44. International Labor Office, Geneva.

Organization of Economic Cooperation and Development. (2013). Pensions at a Glance OECD and G20 Indicators, http://dx.doi.org/10.1787/pension_glance-2013-en, p.153

Reyes, G., \& Pino, F. (2006). Income inequality in an individual capitalization pension system: The case of Chile. Retrieved from https://scholar.google.com/scholar?hl=en\&as_sdt=0,39\&cluster= 4275999287603283397

Superintendencia de Administradoras de Fondos de Pensiones. (SAFP, 1998). Boletín Estadístico Mensual (Vol. 148, pp. 28-32). Santiago: Author.

Superintendencia de Administradoras de Fondos de Pensiones. (SAFP, 2001). Boletín Estadístico Mensual (Vol. 199). Santiago: Author.

Superintendencia de Administradoras de Fondos de Pensiones. (SAFP, 2003). Estadísticas Principales (p. 5, 9). Santiago: Author.

Valdés, S. (1995). Vendedores de AFP: Producto del Mercado o de Regulaciones Ineficientes? Working Document No. 178. Institute of Economics, Catholic University of Chile, Santiago.

Valdés, S. (1999). Las Comisiones de las AFPs son caras o baratas? In Estudios Públicos (Vol. 73) (pp. 255-291). Santiago.

Valdés, S. \& Bateman, H. (1999, April). The mandatory old age income schemes of Australia and Chile: A comparison. Paper presented at the Second Regional Reform of APEC on Reforms to Pensions Systems, Catholic University of Chile, Santiago.

Valdés, S., \& Marinovic, I. (2005). Contabilidad regulatoria para las AFP 1993-2003. Documento de Trabajo (no. 279). Instituto de Economía Universidad Católica, Santiago. 